\title{
MTT Assay of Psidium cattleianum
}

\author{
Christine Men Martinz ${ }^{1}$, Kristina Johnn ${ }^{2}$ and Mirian Marubayashi Hidalgo ${ }^{3}$ \\ ${ }^{1}$ Department of Dentistry, Santa Fé do Sul Dental School, Integrated Faculties of Santa Fé do Sul - FUNEC, Santa Fé do Sul, São Paulo, Brazil \\ ${ }^{2}$ Department of Pediatric Dentistry and Public Health, Araçatuba Dental School, Univ. Estadual Paulista - UNESP, Araçatuba, São Paulo, Brazil \\ ${ }^{3}$ Department of Dental Materials and Prosthodontics, Aracatuba Dental School, Univ Estadual Paulista - UNESP, Araçatuba, São Paulo, Brazil
}

Corresponding author: Prof Christine Men Martinz, Department of Dentistry, Santa Fé do Sul Dental School, Integrated Faculties of Santa Fé do Sul-FUNEC 477, Mangara avenue, Santa Fé do Sul, São Paulo, Brazil, Tel: +555233086000; E-mail: christinemen@gmail.com

Received date: May 14, 2016; Accepted date: May 17, 2017; Published date: May 27, 2017

Copyright: (C) 2017 Martinz CM, et al. This is an open-access article distributed under the terms of the Creative Commons Attribution License, which permits unrestricted use, distribution, and reproduction in any medium, provided the original author and source are credited.

Citation: Martinz CM, John K, Hidalgo MM. MTT Assay of Psidium cattleianum. Periodon Prosthodon. 2017, 3:2.

\section{Abstract}

The point of this review was to assess the ethanolic concentrate of Psidium cattleianum biocompatibility by basic and utilitarian cell reasonability support. Cell practicality was broke down after 1, 3, 6, 10 and 24 hours of hatching by Exclusion Method with trypan blue and MTT measure, utilizing human mononuclear cells [PBMC] and human periodontal tendon [PDL] cells in culture. Positive control utilized was RPMI cell culture medium and negative control was ethanol $80 \%$. The got information were subjected to measurable examination at a criticalness level of 5\%. By trypan blue examine, ethanolic remove displayed a homogeneous execution of PBMC from the $1 \mathrm{~h}$, with normal reasonability in the vicinity of 30 and half $(p>0.05)$. By MTT examine, the outcomes demonstrated the adequacy of the ethanolic concentrate of Psidium cattleianum in keeping up the utilitarian reasonability of the periodontal tendon cells to $10 \mathrm{~h}(\mathrm{p}>0.05)$, displaying values more noteworthy than the RPMI control. In both techniques, it can be watched that the concentrate properties can kill the cytotoxic impact of its diluent ethanol $80 \%$, which indicated normal practicality almost zero $(p<0.05)$. The biocompatibility by auxiliary and useful cell feasibility support was viewed as satisfactory to ethanolic concentrate of Psidium cattleianum and further reviews ought to be performed to demonstrate its utilization as another option to water system arrangement generally utilized as a part of regular practice.

Keywords: Palavras-chave; Psidium; Cell survival; Materials testing

\section{Introduction}

Endodontic treatment expected to reestablish the typicality of apical and periapical tissues [1-4] through a root channel framework profound cleaning and cleansing, keeping in mind the end goal to control pathogenic microorganisms and the entire three-dimensional fixing utilizing root trench sealers [5-7].

To accomplish this objective, water system and goal of the root waterway framework, combined with instrumentation, makes a critical stage out of radical endodontic treatment, the synthetic mechanical readiness. At this stage, the disease is battled and the tissue aggravation can be lessened [8-10].

At present, there is the straightforwardness, speed and common sense of instrumentation systems utilizing turning or responding records and one of a kind documents [11-13], authenticating to an endodontic treatment in a solitary area [14]. In this manner, the utilizing of a decent irrigant arrangement is winding up plainly very fundamental, since its activity time is diminished.

A perfect irrigant arrangement ought to expel the mash tissue flotsam and jetsam and necrotic tissue, and also the spread layer. In this way, it will aid the exhausting of the mash depression, making a space for putting the further intracanal prescription as well as obturation. Moreover, the irrigant specialist must grease up the root waterway. In instances of mash rot treatment, the watering arrangement ought to go about as a variable of antimicrobial movement and disinfectant. For the biopulpectomy treatment, it must help with evacuating organic tissue and draining stagnation. Notwithstanding the kind of treatment to be played out, the inundating arrangement must present biocompatibility, with a specific end goal to keep the respectability of the periapical structures, not advancing aggravation of the rest of the mash tissue and permitting repair [15-18]

There are a few substances utilized as flooding specialist, for example, hemostatic operators, halogenated mixes, cleansers, chelators, acids and peroxides; in any case, there is not a substance that has the qualities to be viewed as perfect. As of now, there is a pattern toward the utilization of common substances and restorative plants $[19,20]$ and inside this unique circumstance, the outcomes exhibited in past reviews with Psidium cattleianum stirred enthusiasm for its utilization as intracanal irrigant arrangement amid endodontic treatment. 
Psidium cattleianum indicates guarantee as intracanal prescription amid endodontic treatment [21-26]. Fluid and ethanol concentrates of Psidium cattleianum have demonstrated noteworthy antibacterial action against oral microbiota, calming and potential anti cariogenic impacts, and tissue biocompatibility [22-24,26]. In any case, deciding the utilization and clinical use of this concentrate requires testing for cytotoxicity, sharpening [25], calming and antimicrobial exercises $[21,22,24,26]$, and different issues.

The writing demonstrates that there is still no learning of cell cytotoxicity of ethanol concentrate. In this way, the point of this review was to assess the ethanolic concentrate of Psidium cattleianum biocompatibility by basic and utilitarian cell practicality upkeep. The theory tried was that ethanolic concentrate of Psidium cattleianum would introduce biocompatibility more prominent than cell culture medium.

\section{Material and Methods}

The venture was affirmed by the Ethics Committee in Research Involving Humans from the Maringa State University.

\section{Concentrate and controls}

The ethanolic concentrate was arranged in like manner to a depicted convention [22]. Culture medium Roswell Park Memorial Institute 1640 [RPMI - Gibco ${ }^{\circledR}$, Life Technologies, USA] was utilized as a positive control and ethanol $80 \%$ filled in as negative control.

\section{Human mononuclear cells (PBMC)}

To acquire the PBMC, $15 \mathrm{ml}$ of venous blood from 4 givers was gotten aseptically in heparinized tubes with 2 drops of Liquemine $^{\circledR}$ (Roche, Switzerland). The cells were confined by the technique depicted by writing $[26,27]$. The tubes were centrifuged and the interface amongst plasma and red platelets were gathered and weakened in sterile phosphatesupported saline (PBS) and set over an intermittent slope Histopaque ${ }^{\circledR}$ (Sigma Chemical Co., USA). After further centrifugation, the leukocytes were expelled through Pasteur pipette and exchanged to another tube. At that point the washing procedure was completed with PBS 3 times. The cel encouraged was resuspended in RPMI (Life Technologies, USA).

\section{Human periodontal tendon cells kept up in culture (PDL)}

The PDL cells were compassionately given by the research center of Applied Virology, Santa Catarina Federal University. The cells were kept in a hatchery $\left(5 \% \mathrm{CO}_{2} / 95 \%\right.$ moistness, $37^{\circ} \mathrm{C}$ ) in cell culture bottles (TTP Techno Plastic Products, Switzerland) containing Dulbecco's MEM (DMEM - Cultilab, Brazil) supplemented with $10 \%$ fetal cow-like serum (FBS Cultilab, Brazil) and $1 \%$ of a blend of penicillin $10,000 \mathrm{UI} / \mathrm{mL}$, streptomycin $20 \mathrm{mg} / \mathrm{mL}$ and amphotericin B $2 \mathrm{mg} / \mathrm{L}$ (PSA Cultilab, Brazil). The way of life medium was changed each 48 or 72 hours. After cell conversion the trypsinization was done utilizing $\quad 0.25 \%$ trypsin arrangement and ethylenediaminetetraacetic corrosive (EDTA - Sigma Chemical Co., USA) for a few minutes to discharge the cells. After balance with RPMI (Life Technologies, USA), the cell encourage was washed, broken down in a crisp culture medium, and aliquoted in containers. Every trypsinization yielded another entry and all through the trial time frame when conjunction, cells were repeated to keep up the way of life's ideal feasibility. The investigations were performed when cells were between the eleventh and twelfth entries [28].

\section{Trypan blue test}

The reasonability was controlled by tiny perception of the cells prohibited by recoloring with trypan blue, an indispensable stain gotten from toluidine. These 2 sorts of cells in a last convergence of $1 \times 10^{6}$ cells $/ \mathrm{mL}$ were hatched in ethanolic concentrate of Psidium cattleianum or controls amid 24 hours at $25^{\circ} \mathrm{C}$. Tests were gathered at 1, 3, 6, 10 and 24 hours and dissected in a Neubauer chamber with an equivalent volume recoloring. Cells were considered not reasonable when impregnated by recoloring or when deteriorated. Three already prepared spectators played out the readings under an optical magnifying lens and communicated the outcomes as rates. They rehashed the procedure 4 times.

\section{MTT assay}

The cells were changed in accordance with $1 \times 10^{4}$ cells $/ \mathrm{ml}$ in RPMI (Life Technologies, USA) with 10\% FBS (Cultilab, Brazil) and 1\% PSA (Cultilab, Brazil), and seeded in 96-well plates (TPP Techno Plastic Products, Switzerland). After hatching $\left(5 \% \mathrm{CO}_{2}\right.$ and $95 \%$ moistness at $37^{\circ} \mathrm{C}$ hatchery) for 24 hours for cell attachment, the way of life medium was disposed of, and the concentrate or control was included. After the hatching times of $1,3,6,10$ and 24 hours, the trial medium was expelled and MTT arrangement was included $(5 \mathrm{mg} / \mathrm{mL}$, MTT-thiazole blue, Sigma Chemical Co., USA). The plates remained in the hatchery amid 3 hours. At that point the MTT arrangement was expelled and dimethylsulfoxide (DMSO - Merck, Brazil) was added to break down formazan precious stones. Cell practicality was controlled by perusing the absorbance of the wells under the wavelength of $550 \mathrm{~nm}$ (ASYS Expert Plus Microplate Reader, Biochrom, UK). The test was additionally performed in triplicate with 4 rehashes.

\section{Factual examination}

Information on the rate of feasible cells were gotten by methods for rejection with trypan blue and PDL cells and PBMC in culture were gathered for the gatherings in a period subordinate way. To dissect these outcomes, it was utilized direct blended impacts models with PROC NLMIXED of SAS variant 9. The consequences of the suitability of PDL cell societies by MTT strategy were subjected to ANOVA Factorial through SAS programming 9.3. The level of measurable centrality was set at $5 \%$ for all investigations. 


\section{Results}

Cell suitability for various media in which cells were put away. The midpoints of cell viabilities kept up in various media, paying little heed to time, are appeared in Table 1. By Trypan Blue system with PBMC, the ethanolic extricate introduced the suitability almost half, higher than the ethanol control $(p<0.05)$. The optical thickness values, which speak to the feasibility of periodontal tendon cells investigated by MTT, the concentrate arrived at the midpoint of was marginally more than twice contrasted with the positive control RPMI. Control of liquor concentrate demonstrated no optical thickness ( $p>0.05)$.

Table 1 Average of cell viability for different media in which cells were stored.

\begin{tabular}{|l|l|l|}
\hline & $\begin{array}{l}\text { Trypan Blue Assay [\%] } \\
\text { - PBMC }\end{array}$ & $\begin{array}{l}\text { MTT [O.D.]1 - } \\
\text { PDL }\end{array}$ \\
\hline $\begin{array}{l}\text { Ethanolic extract of } \\
\text { Psidium cattleianum }\end{array}$ & 49 & 1.38 \\
\hline RPMI [positive control] & 92 & 0.55 \\
\hline $\begin{array}{l}\text { Ethanol 80\% [negative } \\
\text { control] }\end{array}$ & $17.3^{*}$ & 0.01 \\
\hline
\end{tabular}

O.D=Optical density. ${ }^{*}$ Statistically significant difference between the negative control - ethanol $80 \%$ - and other media $(p<0.05)$ for the Trypan Blue assay.

Cell viability after incubation and throughout the experimental period

The cell viability maintained in the test medium and its control over a 24 hours period is described in Figure 1. Figure 1A represents Trypan Blue assay with PBMCs. Within the first hour of incubation, the cells maintained in ethanolic extract showed a reduction in cell viability and thereafter maintained that viability with homogeneous performance over time. The control solution had cell viability below $10 \%$, differing statistically from other medias $(p<0.05)$. Figure 1B represents the optical density values obtained by periodontal ligament cells analyzed by MTT. The results have demonstrated superior functional performance to ethanolic extract until 10 hours later, suffering a drop in 24 hours. Negative control ethanol presented lower values since the first hour $(p<0.05)$.

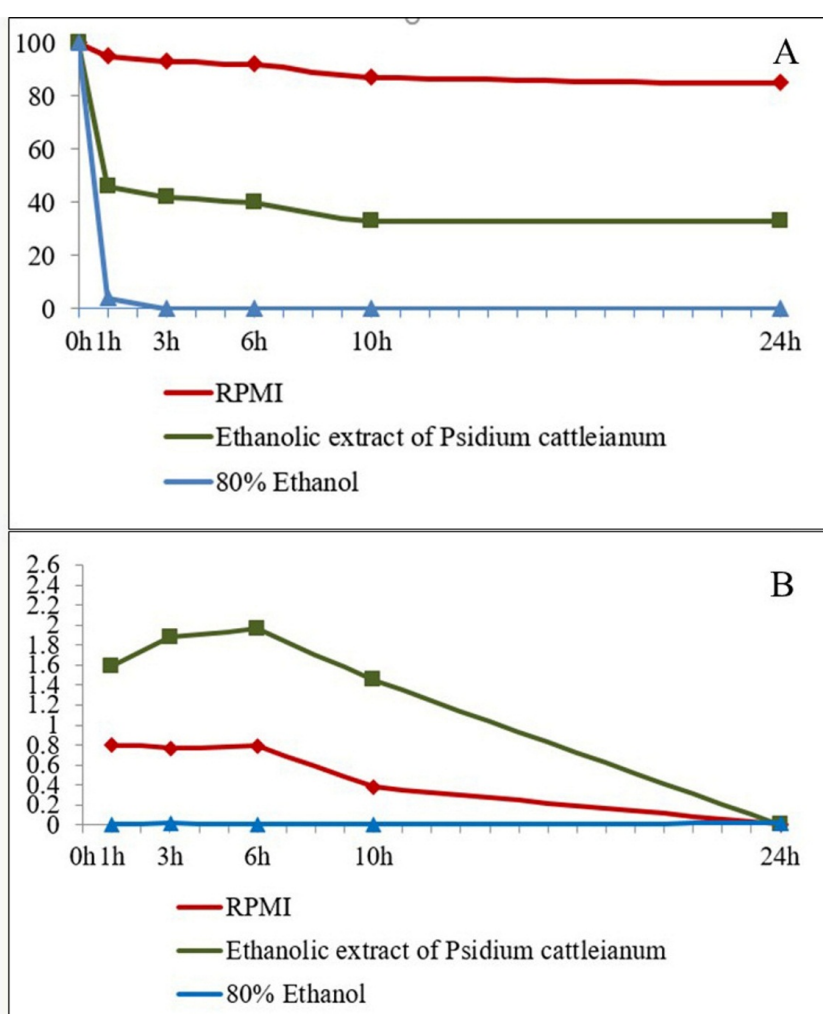

Figure 1 Relative percentage of average viability of cells incubated in different media throughout the experimental period. A- exclusion methodology by Trypan Blue dye with PBMC; B-MTT Methodology with the PDL. *Statistically significant difference from the negative control Alcohol $80 \%$ compared to another media.

\section{Discussion}

This research aimed to verify cellular and functional viability of PBMC and PDL kept in ethanol extract of Psidium cattleianum over 24 hours. Cell viability was homogeneous over time, averaging between 30 and $50 \%$ for PBMC. The functional viability of PDL was high until 10 hours, with a considerable drop after this period. Ethanolic extract neutralized part of the cytotoxic effect of its diluent $80 \%$ alcohol. However, the hypothesis tested was rejected, because even though ethanolic extract of Psidium cattleianum presented good biocompatibility, it was not greater than cell culture medium.

PBMC were used due to its ease and speed of obtaining. PDL cells were used to approach in vitro research with the reality, once they are the cells directly involved in the healing after endodontic treatment [16]. These cells also permit standardization of cell concentration, by the way it is easy to detect tiny possible changes.

Trypan blue assay is commonly used in assessing viability and allows analysis of physical integrity of the cell membrane $[16,27-29]$. However, this methodology does not evaluate the real metabolic capacity of cell. To overcome this gap, we 
carried out the MTT assay, quantifying the reduction of MTT salt. Through metabolism, MTT salt becomes formazan salt, which is purplish and soluble in DMSO. This makes it possible to quantify cellular metabolic activity via NADPH-dependent oxidoreductases. Reduction of MTT to formazan is directly proportional to mitochondrial activity and cell viability [28].

The viability of PBMC maintained in the ethanolic extract of Psidium remained homogeneous over time, averaging between 30 and $50 \%$ lower than the control RPMI. The RPMI is a salts mixture enriched with amino acids, vitamins and other essential components for cell growth which acts as a nutrient solution. Its $\mathrm{pH}$ and osmolarity are ideal for cell culture, usually being used as a positive control for the experiment. These cells maintained in ethanolic extract of Psidium showed a lower viability than in RPMI control, even though no statistical difference. The homogeneity was observed in the results from the first time when there was a reduction on viability.

The functional viability of PDL was two times higher when maintained in the extract than in RPMI, and increased after 10 hours. This high functional viability can be justified because of its natural antioxidants [30], and the production and release of factor growth mediators.

Unlike RPMI, 80\% ethanol is considered unfavorable for cell culture media due to protein denaturation, cell lysis and cytotoxic effect [25]. However, comparing $80 \%$ ethanol with ethanolic extract of Psidium cattleianum, it can be stated that Psidium neutralized by $50 \%$ the harmful effect of ethanol.

In addition, to maintaining the integrity of the membrane and the functional metabolic activity of the cells maintained in the ethanolic extract has been shown to have antimicrobial activity and being able to influence the capacity demineralization of hydroxyapatite by microorganisms [25]. Brighenti et al. [22] showed that may reduce demineralization of the enamel, acidogenic potential, the viability of microorganisms and the production of extracellular polysaccharide.

Thinking about Psidium cattleianum uses as an endodontic irrigant, it can be observed that it presents acceptable cytotoxicity and other properties previously described, as its anti-inflammatory and anti-microbial power. Thus, the results demonstrated that the ethanolic extract was able to maintain the PBMC viability from 30 to $50 \%$ with homogenous results throughout the experimental period and maintained PDL functional viability higher than the positive control and deactivates the cytotoxic effect of its diluent, $80 \%$ ethanol.

\section{Conclusion}

Biocompatibility by structural and functional cell viability maintenance was considered acceptable to ethanolic extract of Psidium cattleianum. The results are promising and further studies should be conducted to his appointment as a possible alternative to irrigating solutions traditionally used in everyday practice.

\section{References}

1. Holland R, de Mello W, Nery MJ, Bernabe PF, de Souza V (1977) Reaction of human periapical tissue to pulp extirpation and immediate root canal filling with calcium hydroxide. Journal of Endodontics 3: 63-67.

2. Katebzadeh N, Sigurdsson A, Trope M (2000) Radiographic evaluation of periapical healing after obturation of infected root canals: An in vivo study. Journal of Endodontics 33: 60-66.

3. Holland R, Otoboni Filho JA, de Souza V, Nery MJ, Bernabé PF, et al. (2003) A comparison of one versus two appointment endodontic therapy in dogs' teeth with apical periodontitis. Journal of Endodontics 29: 121-124.

4. Nakamura H (2004) Success rate of endodontic treatment of teeth with vital and nonvital pulps. A meta-analysis. Oral Surg Oral Med Oral Pathol Oral Radiol Endod 97: 95-99.

5. Gomes-Filho JE, Bernabé PFE, Nery MJ, Otoboni-Filho JA, DezanJunior $E$, et al. (2008) Reaction of rat connective tissue to a new calcium hydroxide-based sealer. Oral Surg Oral Med Oral Pathol Oral Radiol Endod 106: 71-76.

6. Gomes-Filho JE, Watanabe S, Gomes AC, Faria MD, Lodi CS, et al. (2009) Evaluation of the effects of endodontic materials on fibroblast viability and cytokine production. Journal of Endodontic 35: 1577-1579.

7. Bernades RA, Campelo AA, Junior DS, Pereira LO, Duarte $M A H$ et al. (2010) Evaluation of the flow rate of 3 endodontic sealers: Sealer 26, AH Plus, and MTA Obtura. Oral Surg Oral Med Oral Pathol Oral Radiol Endod 109: 47-49.

8. Batista VE, Olian DD, Mori GG (2014) Diffusion of hydroxyl ions from calcium hydroxide and Aloe vera pastes. Braz Dent J 25: 212-216.

9. Kawashima N, Wadachi R, Suda H, Yeng T, Parashos P (2009) Root canal medicaments. International Dental Journal 59: 5-11.

10. Mohammadi Z, Abbott PV (2009) Antimicrobial substantivity of root canal irrigants and medicaments: a review. Australian Endodontic Journal 35: 131-139.

11. Basmaci F, Oztan MD, Kiyan M (2013) Ex vivo evaluation of various instrumentation techniques and irrigants in reducing $\mathrm{E}$. faecalis within root canals. Int Endod J 46: 823-830.

12. Nabeshima CK, Caballero-Flores H, Cai S, Aranguren J, Borges Britto ML, et al. (2014) Bacterial Removal Promoted by 2 Singlefile Systems: Wave One and One Shape. J Endod 19: 99-109

13. Martinho FC, Gomes AP, Fernandes AM, Ferreira NS, Endo MS, et al. (2014) Clinical comparison of the effectiveness of singlefile reciprocating systems and rotary systems for removal of endotoxins and cultivable bacteria from primarily infected root canals. J Endod 40: 625-629.

14. Vera J, Siqueira JF Jr, Ricucci D, Loghin S, Fernández $\mathrm{N}$, et al. (2012) One- versus two-visit endodontic treatment of teeth with apical periodontitis: a histobacteriologic study. J Endod 38: 1040-1052.

15. Misuriya A, Bhardwaj A, Bhardwaj A, Aggrawal S, Kumar PP, et al. (2014) A comparative antimicrobial analysis of various root canal irrigating solutions on endodontic pathogens: an in vitro study. J Contemp Dent Pract 15: 153-160.

16. Willershausen I, Wolf TG, Schmidtmann I, Berger C, Ehlers V, et al. (2015) Survey of root canal irrigating solutions used in dental practices within Germany. Int Endod J 48: 654-660. 
17. Cruz A, Vera J, Gascón G, Palafox-Sánchez CA, Amezcua O, et al. (2014) Debris remaining in the apical third of root canals after chemomechanical preparation by using sodium hypochlorite and glyde: an in vivo study. J Endod 40: 1419-1423

18. Ravikumar J, Bhavana V, Thatimatla C, Gajjarapu S, Reddy SG, et al. (2014) The effect of four different irrigating solutions on the shear bond strength of endodontic sealer to dentin - An In-vitro study. J Int Oral Health 6: 85-88

19. Verma MK, Pandey RK, Khanna R, Agarwal J (2014) The antimicrobial effectiveness of $25 \%$ propolis extract in root cana irrigation of primary teeth. J Indian Soc Pedod Prev Dent 32: 120-124.

20. WHO (2002) Traditional Medicine Strategy. World Health Organization 2002-2005. WHO, Geneva.

21. Alves PM, Queiroz LM, Pereira JV, Pereira MS (2009) In vitro antimicrobial, antiadherent and antifungal activity of Brazilian medicinal plants on oral biofilm microorganisms and strains of the genus Candida. Revista da Sociedade Brasileira de Medicina Tropical 42: 222-224.

22. Brighenti FL, Luppens SBI, Delbem ACB, Deng DM, Hoogenkamp MA, et. al. (2008) Effect of Psidium cattleianum leaf extract on Streptococcus mutants viability, protein expression and acid production. Caries Research 42: 148-154.

23. Scur MC, Pinto FG, Pandini JA, Costa WF, Leite CW, et al. (2016) Antimicrobial and antioxidant activity of essential oil and different plant extracts of Psidium cattleianum Sabine. Braz J Biol 76: 101-108.
24. Jaiarj $P$, Khoohaswan $P$, Wongkrajang $Y$, Peungvicha $P$ Suriyawong P, et al. (1999) Anticough and antimicrobial activities of Psidium guajava Linn. leaf extract. Journal of Ethnopharmacology 67: 203-212.

25. Lozoya X, Meckes M, Aboud-Zaid M, Tortoriello J, Nozzolillo C, et al. (1994) Quercetin glycosides in Psidium guajava L. leaves and determination of spasmolytic principle. Archives of Medical Research 25: 11-15.

26. Menezes TEC, Delbem ACB, Brighenti FL, Okamoto AC, GaettiJardim Jr E (2010) Protective efficacy of Psidium cattleianum and Myracrodruon urundeuva aqueous extracts against caries development in rats. Pharmaceutical Biology 48: 300-305.

27. Boyum A (1968) Isolation of mononuclear cells and granulocytes from human blood. Scandinavian Journal of Clinical and Laboratory Investigation 21: 77-89.

28. Oh YH (2005) Cryopreservation of human teeth for future organization of a tooth bank--a preliminary study. Cryobiology 51: 322-329.

29. Blömlof L, Otteskog P (1980) Viability of human periodontal ligament cells after storage in milk or saliva. Scand J Dent Res 88: 436-440.

30. Akinola OB, Oladosu OS, Dosumu OO (2007) Spermatoprotective activity of the leaf extract of Psidium guajava Linn. Niger Postgrad Med J 14: 273-276. 